Chirurgia (2020) 115: 323-333

No. 3, May - June

Copyright@ Celsius

http://dx.doi.org/10.21614/chirurgia.115.3.323

\title{
Analysis of Clinical-Pathological Data with Impact on Overall Survival in Male Breast Carcinoma: An International Multi-Institutional Study of 217 Cases
}

\author{
Monica Boros ${ }^{1}$, Erika Resetkova ${ }^{2}$, Calin Molnar ${ }^{3}$, Cristian Podoleanu ${ }^{4 *}$, Alis Dema ${ }^{5}$, Maria Olinca ${ }^{6,7}$, \\ Isabel Alvarado-Cabrero ${ }^{8}$, Rares Buiga ${ }^{9}$, Simona Stolnicu ${ }^{10}$ \\ 'Department of Morphological Disciplines, Faculty of Medicine and Pharmacy, University of Oradea, Romania \\ 2Department of Pathology, MD Anderson Cancer Center, Houston, USA \\ ${ }^{3}$ Department of Surgery, University of Medicine, Pharmacy, Science, and Technology of Târgu Mureș, Romania \\ ${ }^{4}$ Department of Internal Medicine, University of Medicine, Pharmacy, Science, and Technology of Târgu Mures, Romania \\ ${ }^{5}$ Department of Pathology, University of Medicine "Victor Babeș" Timișoara, Romania \\ ${ }^{6}$ INCD Victor Babes, Bucharest, Romania \\ ${ }^{7}$ University of Medicine Carol Davila, Bucharest, Romania \\ ${ }^{8}$ Department of Pathology, Oncologic Institute, Mexico City, Mexico \\ 'Department of Pathology, Oncologic Institute "I. Chiricuță" Cluj, Romania \\ ${ }^{10}$ Department of Pathology, University of Medicine, Pharmacy, Science, and Technology of Târgu Mureș, Romania
}

*Corresponding author: Cristian Podoleanu, MD, PhD Department of Internal Medicine University of Medicine, Pharmacy, Science, and Technology of Tirgu Mures 38 Gheorghe Marinescu Street, Tirgu Mures 540139, Romania E-mail: podoleanu@me.com

Abbreviations

OS - overall survival

LN - lymph node

CT - chemotherapy

NA - not available

Received: 08.05.2020 Accepted: 12.06 .2020

\section{Rezumat}

Analiza parametrilor clinico-patologici cu impact asupra supraviețirii generale în carcinomul mamar la bărbat: studiu internațional multiinstitutional a 217 cazuri

Introducere: Obiectivul studiului nostru a fost reprezentat de evaluarea parametrilor clinico-patologici cu impact asupra supraviețuirii în 217 carcinoame mamare la bărbat.

Metodologie:Am apreciat supraviețuirea generală la 5 şi la 10 ani, precum şi supravietuirea corelată cu vârsta, cu dimensiunea tumorii, cu tipul microscopic, gradul histologic, statusul limfonodulilor axilari şi cu profilul molecular.

Rezultate: În cadrul lotului studiat, vârsta medie a fost de 62 de ani (minimă: 18, maximă: 85). Tumora a afectat mai frecvent sânul drept $(52.53 \%)$, şi a fost mai frecvent de tip histologic NST (86.63\%), grad histologic 2 de malignitate (55.4\%), stadiu T2 (54.41\%), asociată cu metastaze în limfonodulii axilari (65.89\%) şi de subtip molecular Luminal A-like (85.29\%). Pozitivitatea receptorilor hormonali a fost observată în $89.71 \%$ cazuri pentru receptori estrogenici, $83.82 \%$ receptori progesteronici şi în $93.29 \%$ la 
cei androgenici. Supraexpresia HER2 a fost evidențiată în $8.33 \%$ dintre cazuri, iar în $75 \%$ dintre cazurile analizate indexul ki67 a fost crescut. Supraviețirea generală la 5 ani a fost de $67.2 \%$, iar cea la 10 ani doar de $48.5 \%$. In cazurile cu metastaze limfonodulare prezente, supravietuirea generală la 5 ani a fost de $59.7 \%$ şi de doar $41.3 \%$ la 10 ani, versus supraviețuirea generală la 5 ani de $92.7 \%$ şi cea la 10 ani de $73.8 \%$ în carcinoamele mamare fără metastaze axilare $(\mathrm{p}=0.003)$.

Concluzie: Vârsta (>60 ani), dimensiunea tumorii, prezența metastazelor limfonodulare axilare şi absența tratamentului oncologic reprezintă factori negativi de prognostic în lotul studiat, însă în analiza multivariată, statusul limfonodulilor axilari $(\mathrm{p}=0.005)$ şi profilul molecular de tip triplu negativ $(\mathrm{p}=0.005)$ sunt singurii factori de prognostic statistic semnificativi.

Cuvinte cheie: carcinoma mamar la bărbat, prognostic, supraviețuire

\begin{abstract}
Background:The aim of this study was to evaluate clinical-pathological parameters with impact on overall survival (OS) in male breast carcinoma (MBC).

Methodology: We assessed OS at 5 years and at 10 years respectively, as well as OS according to age, tumor size, microscopic type, histological grade, axillary lymph node status, and molecular profile.

Results: Two hundred seventeen cases, with a mean age of 62 (range: 18- 85), right breast involvement (52.53\%), invasive carcinoma of no special type (86.63\%), G2 histological grade (55.4\%), T2 (54.41\%), N+ (65.89\%) and Luminal A molecular subtype (85.29\%) were identified. ER, PR and AR were positive in $89.71 \%, 83.82 \%$ and $93.29 \%$ of cases, respectively. HER2 was overexpressed in $8.33 \%$ of cases and a high Ki67 proliferation index was present in $75 \%$ of cases. The 5 -year OS was $67.2 \%$, whereas 10 -year OS was $48.5 \%$; OS was $92.7 \%$ at 5 years and $73.8 \%$ at 10 years in axillary lymph node (LN) negative cases, while OS was $59.7 \%$ at 5 years and $41.3 \%$ at 10 years in axillary $\mathrm{LN}$ positive cases $(\mathrm{p}=0.003)$.

Conclusions: Age at diagnosis ( $>60$ years), larger tumor size, presence of LN metastases and absence of oncological treatment are negative factors influencing prognosis, with only axillary LN status $(\mathrm{p}=0.005)$ and triple negative molecular profile $(\mathrm{p}=0.05)$ being statistically significant unfavorable independent prognostic parameters in a multivariate analysis.
\end{abstract}

Key words: male breast cancer, prognosis, survival

\section{Introduction}

Male breast carcinoma (MBC) is rare, accounting for less than $1 \%$ of all cancers in men and less than $1 \%$ of all breast cancer diagnoses in the USA (1). However, in recent decades the annual incidence increased to 1.9 per 100,000/year in 2009-2013, with mortality rates $0.4 / 100,000 \quad(2010-2014)$, and 5-year relative survival of $84 \%(2006-2012)$ (2). Lesions in males tend to be more advanced stage on diagnosis, with almost half of male breast cancer diagnosed in stage III and IV (3).
Most cases present late because of a lack of awareness of the existence of such a malignancy in males and ignorance of the related risk factors as well as a lack of screening. Due to its rarity, the epidemiology, tumor behavior, treatment, and prognosis remain poorly understood (4). The objective of our study was to evaluate clinical-pathological parameters in correlation with overall survival (OS) in MBC. A better understanding of this tumor will lead to an earlier detection, as well as a better management with the goal of decreasing mortality due to MBC worldwide. 


\section{Material and Methods}

\section{Patient Characteristics}

We carried out a retrospective study that included 217 cases of MBCs admitted to 6 international institutions (MD Anderson Cancer Center Houston, USA, Oncologic Institute Mexico City, Mexico, Tirgu-Mures Emergency County Clinical Hospital, Romania, Oncologic Institute Cluj-Napoca, Romania, County Clinical Hospital Timisoara, Romania and Victor Babes Institute from Bucharest, Romania) between 1999-2015. The patients were diagnosed using tru-cut biopsy, following which they underwent excisional biopsy or total mastectomy, sentinel lymph node, axillary lymph node dissection (when indicated), and oncological treatment. During the present study, therapeutic strategies for male breast cancer followed the patterns of the recommendations for breast cancer in females (radiotherapy, hormonotherapy and/or chemotherapy) and included into the international guidelines. Each pathology report of every patient was re-analyzed, slides from both biopsy and surgical specimen (when available) were reviewed by an international expert in breast pathology in all cases (SS), and data concerning the age of patients, the size of tumor focus/foci, the microscopic type, and the histological grade of the tumor, the number of axillary lymph nodes with metastases were included in spreadsheets. Also, data regarding the surgical and oncological treatment as well as the molecular profile of the tumor including Estrogen receptors (ER), Progesterone receptors (PR), Ki67 index, and HER2 score as well as Androgen receptors (AR) were also included and analyzed.
Patients were followed for a mean period of 59.6 months (range: 7-168 Months), by studying medical records, oncology "registries" and data from the "Population Survey Offices" regarding survival. We assessed OS at 5 years and at 10 years respectively, as well as OS according to age, tumor size, microscopic type, histological grade, axillary lymph node status, and molecular profile.

Inclusion criteria were the following: all patients were diagnosed with invasive and/or in situ breast cancer, treated with mastectomy or excisional biopsy, axillary lymph node dissection (when indicated) as well as standard oncological treatment (according to international guidelines). Patients presenting with second cancers on initial diagnosis were excluded.

The primary endpoint was survival of corresponding cases. Patients who could not be reached or who refused to provide information for any reason were considered lost to follow-up.

\section{Diagnostic Criteria}

The microscopic type of the tumor was assessed according to WHO 2012 classification of breast tumors (5) and histological grade was established using the modified Nottingham system (6). The IHC pattern, complemented with ERB2 FISH, allowed the identification of clinically-defined, treatment-oriented subtypes, according to AJCC, 8th edition, and were as follows: Luminal A-like (ER+/-PR positive), Luminal B-like (ER+/-PR positive and HER2 positive), HER2-like (HER2positive and negative hormone receptor expression) and Triple negative (TN: ER-, PR-, HER2-)(7). The antibody panel is shown in Table 1, alongside dilution (Table 1).

Table 1. Specifications of various antibodies used in the study

\begin{tabular}{lccl}
\hline Antibody & Clone & Dilution & Vendor \\
\hline Androgen Receptor & AR27 & $1: 50$ & Novocastra \\
\hline Estrogen Receptor & $6 \mathrm{~F} 11$ & $1: 100$ & Novocastra \\
\hline Progesterone Receptor & 312 & $1: 100$ & Novocastra \\
\hline Ki67 & MM1 & $1: 200$ & Novocastra \\
\hline HER2 & CB11 & $1: 200$ & Novocastra \\
\hline
\end{tabular}

Abreviation: HER2, Human Epidermal growth factor receptor 2 
All markers (ER, PR, Ki67, HER2, AR) were performed on paraffin blocks in one single center and interpreted by one pathologist (SS). In this study, we interpreted tumor foci as ER, $\mathrm{PR}$, and AR positive if expression was observed in more than $1 \%$ of the nuclei of tumor cells, while analyzing the total area of the tumor, regardless of staining intensity of the expression, with positive internal control. Ki67 index was defined as low (when $<14 \%$ of all tumor cell nuclei were positive) or high $(\geq 14 \%)$ by assessing the whole section and recording the overall average score (8). 0 and 1+HER2 scores were considered negative, and scores 2+ (confirmed with FISH) and 3+ were considered positive.

\section{Statistical Analyses}

Data were tabulated using Microsoft Excel (Microsoft) software and analyzed using SPSS for Microsoft Windows, version 20.0 (Chicago, IL, USA). OS was defined as the time from the surgery until the death by any cause. Survival curves and univariate analysis were calculated according to the Kaplan Meier method, and the log rank test was used to compare groups. Hazard ratios (HRs) and 95\% confidence intervals (CIs) were estimated using the Cox proportional hazards regression model. $\mathrm{p}<0.05$ was considered statistically significant.

All subjects from all the 6 involved institutions gave their informed consent for inclusion and for publication of any associated data before participating in the study. The study was conducted in accordance with the Declaration of Helsinki, and the protocol was approved by the Ethics Committee (ethical approval code number: 13775/2019).

\section{Results}

Of a total of 217 male patients with breast cancer, non-invasive carcinoma was diagnosed in only 8 cases $(3.68 \%)$, of which we identified 6 cases of papillary in situ lesions (papillary in situ carcinoma, papillary encapsulated and solid carcinoma) and 2 cases of ductal in situ carcinoma (DCIS) while the remaining 209 cases presented with invasive, with/without an in situ (usually of DCIS-type) component.

Median age was 62 years (range: 18-85 years). Only 3 cases were diagnosed before the age of 30 years and $34(15.66 \%)$ patients under 50 years of age; more than $4 / 5$ of breast cancers in this series were diagnosed at age 50 or over (183 patients, $84.33 \%$ cases). Table 2 shows our patients' disease characteristics in terms of age, laterality, tumor size, microscopic type, histological grade, lymph node status, and molecular classification (Table 2). In $52.53 \%$ of cases (114 cases) the tumor was located in the right breast, and in $47.46 \%$ of cases (103 cases) the tumor was left seated. Eleven (5.07\%) carcinomas were classified as multiple (multifocal/multicentric), showing more than one invasive tumor focus in the same breast.

Tumor size was assessed during macroscopic sampling of the breast tumor and correlated with the microscopic size. In our study, 8 cases $(3.68 \%)$ were T0, 35 cases $(25.73 \%)$ were included in T1 category, 74 cases (54.41\%) in T2, 11 cases in T3 (8.09\%), and 16 cases were T4 category (11.76\%) (Fig. 1). In this study, 81 patients were Tx (with no available data regarding the size of the tumor).

Invasive carcinoma of no special type (NST) was the most common histological type, diagnosed in $86.63 \%$ cases $(188 / 217)$, followed by invasive mixed type in 9 of 217 cases $(4.14 \%)$, and lobular invasive carcinoma type in $1.84 \%$ (4/217 cases). In only 3 of 217 patients (1.38\%), the diagnosis of papillary invasive carcinoma was established. Other histological types of tumors such as invasive micropapillary carcinoma $(0.46 \%)$, carcinoma with neuroendocrine differentiation $(0.92 \%)$, and apocrine invasive carcinoma $(0.92 \%)$ were very rarely diagnosed in this series. In most of the cases the tumor was histological grade $2(55.4 \%)$, followed by grade $3(25 \%)$, while in only $19.59 \%$ of cases the tumor was histological grade 1. Data regarding the presence of lymph node metastases (LNM) were available in 129 of 217 cases. Lymph node metastases were present in $65.89 \%$ cases and absent in $34.11 \%$ of cases.

Molecular profile based on surrogate markers was performed in 204 patients. Most 
Table 2. Clinical and pathological characteristics of 217 male breast carcinoma in term of laterality, age, tumor size, morphological subtype, and histological grade, focality, lymph node status and imunohistochemical profile

\begin{tabular}{|c|c|c|}
\hline Characteristics & Number (n) & $\%$ \\
\hline \multicolumn{3}{|l|}{ Laterality } \\
\hline Right & 114 & $52,53 \%$ \\
\hline Left & 103 & $47,46 \%$ \\
\hline \multicolumn{3}{|l|}{ Age in years } \\
\hline Median & 62 & \\
\hline Range & $18-85$ & \\
\hline \multicolumn{3}{|c|}{ Morphologic subtype } \\
\hline NST & 188 & $86.63 \%$ \\
\hline APO & 2 & $0.92 \%$ \\
\hline LIC & 4 & $1.84 \%$ \\
\hline MIC & 1 & $0.46 \%$ \\
\hline MIXED & 9 & $4.15 \%$ \\
\hline NEU & 2 & $0.92 \&$ \\
\hline PAP & 3 & $1.38 \%$ \\
\hline DCIS & 8 & $3.68 \%$ \\
\hline \multicolumn{3}{|l|}{ Focality } \\
\hline Unifocal & 206 & $94.93 \%$ \\
\hline Multiple & 11 & $5.07 \%$ \\
\hline \multicolumn{3}{|l|}{ Histologic grade } \\
\hline 1 & 29 & $19.59 \%$ \\
\hline 2 & 82 & $55.4 \%$ \\
\hline 3 & 37 & $25 \%$ \\
\hline NA & 69 & \\
\hline \multicolumn{3}{|l|}{ Tumor size } \\
\hline$\leq 2 \mathrm{~cm}$ & 35 & $25.73 \%$ \\
\hline $2-5 \mathrm{~cm}$ & 74 & $54.41 \%$ \\
\hline$\geq 5 \mathrm{~cm}$ & 27 & $19.85 \%$ \\
\hline NA & 81 & \\
\hline \multicolumn{3}{|c|}{ Lymph node metastases } \\
\hline NO & 44 & $34.11 \%$ \\
\hline $\mathrm{N}+$ & 85 & $65.89 \%$ \\
\hline NX & 88 & \\
\hline \multicolumn{3}{|c|}{ Imunohistochemical profile } \\
\hline $\mathrm{ER}+$ & 183 & $89.71 \%$ \\
\hline $\mathrm{PR}+$ & 171 & $83.82 \%$ \\
\hline Her $2+$ & 17 & $8.33 \%$ \\
\hline $\mathrm{AR}+$ & 153 & $93.29 \%$ \\
\hline$\uparrow \mathrm{Ki} 67$ & 91 & $75.21 \%$ \\
\hline \multicolumn{3}{|c|}{ Molecular subtype } \\
\hline Luminal $A$ & 174 & $85.29 \%$ \\
\hline Luminal B & 16 & $7.84 \%$ \\
\hline HER2 positive & 1 & $0.49 \%$ \\
\hline Triple Negative & 13 & $6.37 \%$ \\
\hline \multicolumn{3}{|l|}{ Treatment } \\
\hline Yes & 54 & $24.89 \%$ \\
\hline No & 163 & $75.11 \%$ \\
\hline
\end{tabular}

Abreviation: NST, No special type invasive carcinoma; APO, Apocrine invasive carcinoma; LIC, Lobular invasive carcinoma; MIC, Micropapillary invasive carcinoma; NEU, Invasive carcinoma with neuroendocrine differentiation; PAP, Papillary invasive carcinoma; DCIS, Ductal carcinoma in situ; NO, axillary lymph node negative; $\mathrm{N}+$, axillary lymph node positive;

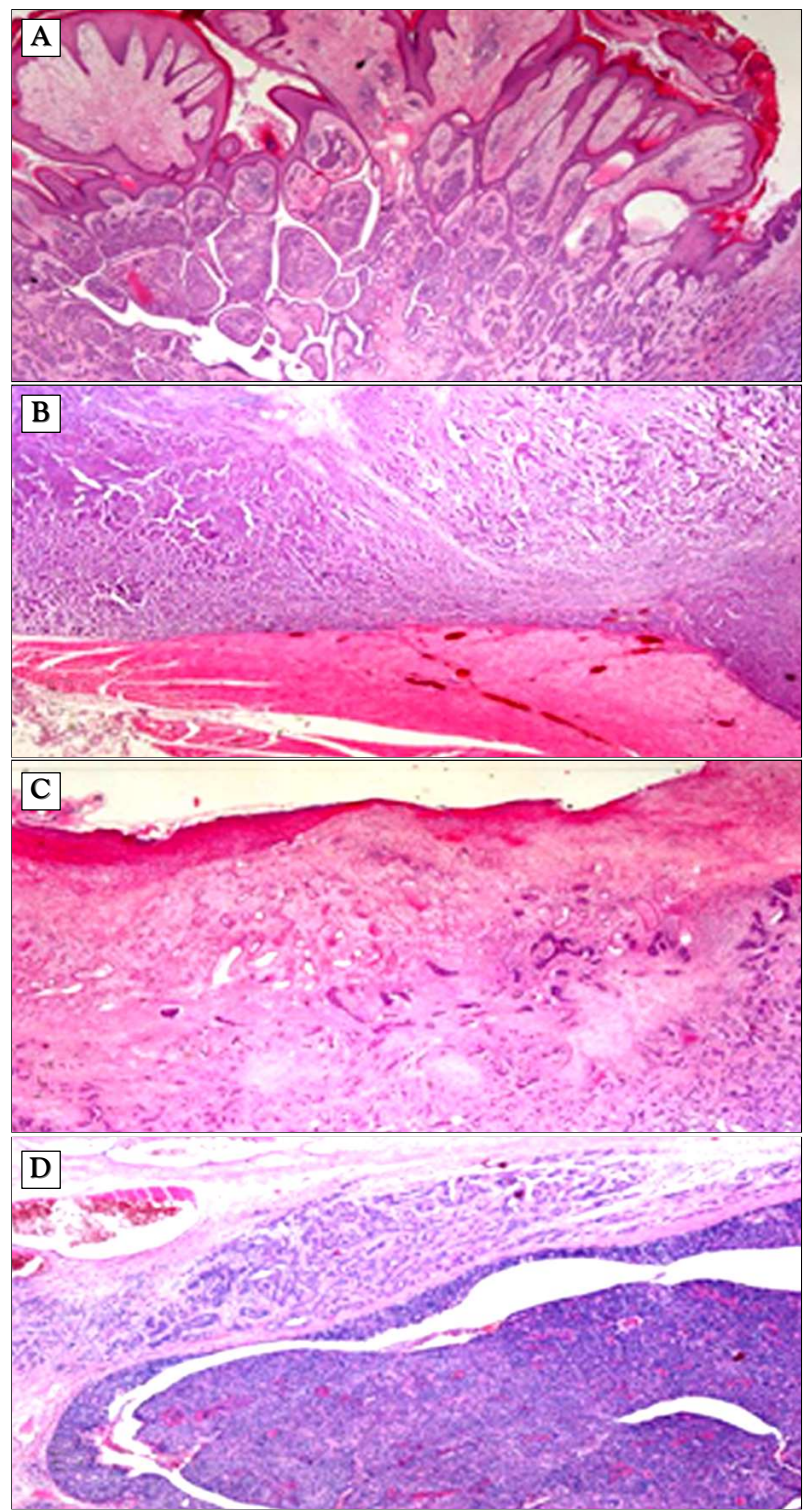

Figure 1. Grade 2 NST invasive carcinoma, infiltrating the nipple (A), infiltrating the pectoralis muscle (B), ulcerating the skin (C); solid papillary breast carcinoma with a focus of grade 1 invasive carcinoma of NST type (D). Hematoxylin and eosin stain, X40 magnification

of the cases were categorized as Luminal A (174/204) (85.29\%), followed by Luminal B (16/204) (7.84\% cases), triple negative 13/204 $(6.37 \%)$ and only 1 case was included in HER2 overexpression category $(0.49 \%)$. Positivity for ER was observed in 89.71\% (183/204) cases, and for PR in 83.82\% (171/204 cases). One hundred sixty-four (80.39\%) cases were positive for both ER and PR, and 19 (9.31\%) 
cases were ER+ and PR negative. In our cohort, we found HER2 overexpression in 17 of 204 cases (8.33\%) cases. Ki67 index was available for only 121 cases; of these, 30/121 $(24.79 \%)$ had a low Ki67 index, while the majority had a high proliferative index (91/121) (75.21\%). AR was the most frequently expressed of hormone receptors (93.29\% positive cases, 153 of 164 cases analyzed), with only $6.71 \%$ interpreted as AR negative. All 11 triple positive cases (ER, PR and HER2+) were also AR positive. Of the 13 triple negative cases, in 10 cases $A R$ was performed: 3 were AR negative, and 7 cases were AR positive.

Fifty-one patients of 217 (23.5\%) had died before the time of analysis. Five (2.3\%) patients are alive with metastasis ( 2 cases with bone metastases, 2 prostate, and 1 lung secondary cc). Kaplan Meier survival analyses revealed a $67.2 \%$ OS at 5 years and $48.5 \%$ at 10 years (Fig. 2A). OS is $92.7 \%$ at 5 years and $73.8 \%$ at 10 years in axillary lymph node negative cases while OS is $59.7 \%$ at 5 year and $41.3 \%$ at 10 years in axillary lymph node positive male patients. Log-rank test between these data shows statistically significant difference $(\mathrm{p}=0.003)$ (Fig. 2B).

Overall survival at $5^{-}$and at 10 years stratified by age ( $<$ and $>60$ years) and by LN status were analysed. OS in patients without $\mathrm{LNM},>60$ years old, at 5 years is $87.4 \%$, while at 10 years it is $61.8 \%$; OS in patients without $\mathrm{LNM},<60$ years old at 5 years is $100 \%$, and at 10 years is $88.9 \%$; OS in patients with LNM, age $>60$ years old at 5 years is $62 \%$, and at 10 years is $42.4 \%$; OS in patients with LNM and $<60$ years old at 5 years is $57.1 \%$ and $40.6 \%$ at 10 years.

We also performed a Kaplan Meier survival analysis in our cohort stratified by histological grade; 5-year OS was $82.6 \%$ and 10-year OS was $49.5 \%$ in histological grade 1 MBC. OS was $65.1 \%$ at 5 years and $46.2 \%$ at 10 years in histological grade 2 cases, while OS was $65.6 \%$ at 5 years and $60.6 \%$ at 10 years in histological grade 3 tumors (log rank test highlighted no statistically significant difference, $\mathrm{p}=0.676$ ) (Fig. 2O). Five year OS was only $31.7 \%$ at 5

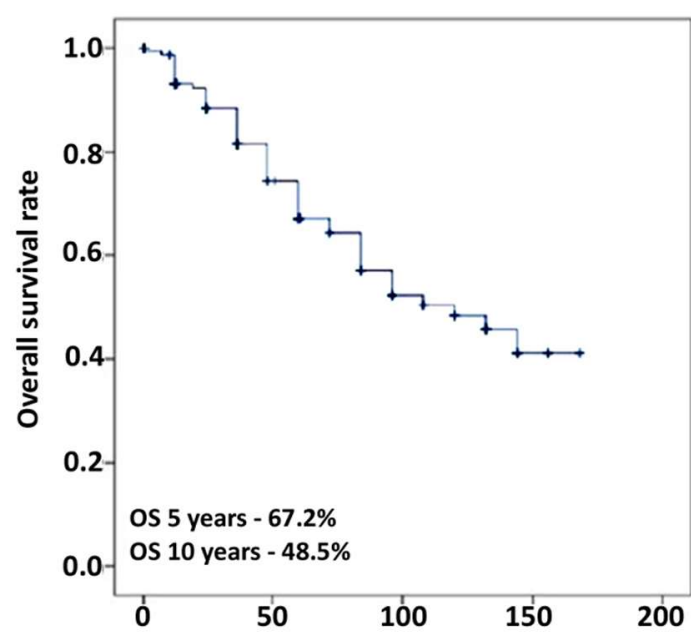

Figure 2A. Kaplan Meier curve for 5-year and 10-year overall survival of the entire cohort/ group.

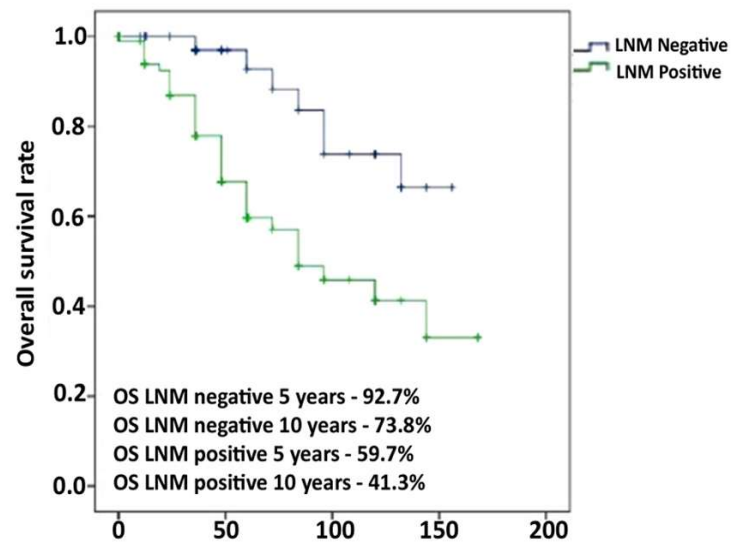

Figure 2B. Kaplan Meier curve for 5-year and 10-year overall survival in axillary lymph node positive versus negative patients.

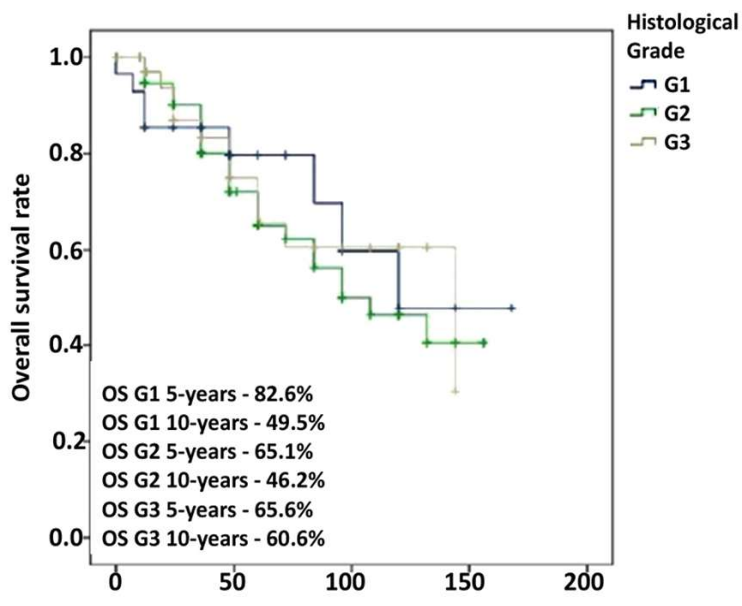

Figure 2C. Overall survival at 5 years and 10 years stratified by histological grade. 
years and $15.9 \%$ at 10 years in triple negative MBCs, compared with 5 years OS of $70.6 \%$ and 10 years OS equal to $51.2 \%$ in all other molecular profiles. (log rank test, $\mathrm{p}=0.04)$ (Fig. 2D).

In univariate analyses $\mathrm{AR}$ positivity was correlated with OS, with hazard ratio of dying of disease $=2.457, \mathrm{p}=0.217(95 \% \mathrm{CI}=0.097-$ 1.698). The results of a multivariate Cox regression analysis are summarized in Table 3. Older age on diagnosis (> 60 years), larger tumor size, presence of LNM, triple negative molecular profile, and the absence of oncological treatment are all negative factors influencing prognosis, but statistically significant are the LN status, with a greater risk of

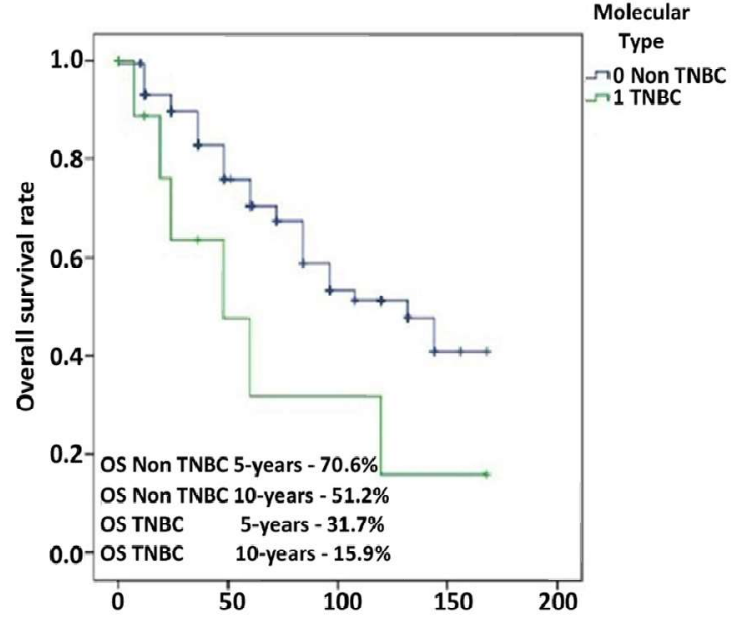

Figure 2D. $\quad 0 S$ at 5 years and 10 years in triple negative MBCs compared with other molecular subtypes (non-triple negative MBCs)

Table 3. Multivariate Cox regression analyses of overal survival and clinical, pathological, and molecular parameters of the entire cohort/group

\begin{tabular}{|c|c|c|c|}
\hline \multirow[t]{2}{*}{ Variables } & \multicolumn{3}{|c|}{ OS } \\
\hline & $\mathrm{HR}$ & $95 \% \mathrm{Cl}$ & $P$ value \\
\hline \multicolumn{4}{|c|}{ Age at diagnosis } \\
\hline$\leq 60$ & Reference & & \\
\hline$>60$ & 1.2804 & $(0.439-1.388)$ & 0,399 \\
\hline \multicolumn{4}{|l|}{ LNM } \\
\hline NO & Reference & & \\
\hline $\mathrm{N}+$ & 3.243 & $(1.423-7.393)$ & $0.005^{*}$ \\
\hline \multicolumn{4}{|l|}{ Tumor Size } \\
\hline $\mathrm{T} 0, \mathrm{~T} 1$ & Reference & & \\
\hline $\mathrm{T} 2, \mathrm{~T} 3, \mathrm{~T} 4$ & 1.64 & $(0.803-3.390)$ & 0.175 \\
\hline \multicolumn{4}{|c|}{ Oncologic treatment } \\
\hline No & Reference & & \\
\hline Yes & 0.899 & $(0.498-1.62)$ & 0.722 \\
\hline \multicolumn{4}{|l|}{ Grade } \\
\hline $\mathrm{G} 1, \mathrm{G} 2$ & Reference & & \\
\hline G3 & 1.14 & $(0.445-1.738)$ & 0.712 \\
\hline \multicolumn{4}{|l|}{$\overline{\mathrm{ER}}$} \\
\hline- & Reference & & \\
\hline+ & 1.14 & $(0.393-1.977)$ & 0.759 \\
\hline \multicolumn{4}{|l|}{$\overline{P R}$} \\
\hline- & Reference & & \\
\hline+ & 1.26 & $(0.369-1.685)$ & 0.539 \\
\hline \multicolumn{4}{|l|}{$\overline{A R}$} \\
\hline- & Reference & & \\
\hline+ & 2.457 & $(0.097-1.698)$ & 0.217 \\
\hline \multicolumn{4}{|l|}{ Ki67 index } \\
\hline- & Reference & & \\
\hline+ & 1.99 & $(0.147-1.718)$ & 0.272 \\
\hline \multicolumn{4}{|l|}{ HER 2+ } \\
\hline- & Reference & & \\
\hline+ & 1.295 & $(0.400-4.199)$ & 0.666 \\
\hline \multicolumn{4}{|l|}{$\overline{T N B C}$} \\
\hline- & Reference & & \\
\hline+ & 2.341 & $(0.994-5.512)$ & $0.05^{*}$ \\
\hline
\end{tabular}

Abreviation: LNM, lymph node metastases; ER, estrogen receptors; PR, progesterone receptors; AR, androgen receptors; HER2, Human Epidermal growth factor receptor 2; TNBC, Triple Negative breast cancers; HR, Hazard Ratio; $\mathrm{Cl}, 95 \%$ confidence interval 
dying of disease $(\mathrm{HR}=3.243), 95 \% \mathrm{CI}=(1.423$ 7.393), $\mathrm{p}=0.005$ and the triple negative molecular profile $\left(\mathrm{HR}=2.341,95 \% \mathrm{CI}=0.994^{-}\right.$ $5.512, \mathrm{p}=0.05$ ).

\section{Discussion}

The global incidence rates of $\mathrm{MBC}$ vary geographically, ranging from $0.49 \%$ in Japan to $15 \%$ in African nations (9). The particular morphological characteristics and distinct biology of this tumor have not been fully studied, and, therefore, knowledge is still lacking regarding MBC. This may constitute one of the reasons why mortality rates are still high in patients with MBC.

In the present study, the medical records as well as histological slides of 217 male patients diagnosed with MBC from 6 international institutions were analyzed with regard to overall survival and its possible association with various clinical, morphological, and molecular parameters.

The median age of MBC in our study, 62 years, was consistent with the literature (between 58-65 years) and is greater than the reported median age for female breast carcinoma (FBC) (<50 years) $(10,11)$. These facts might reside in a lack of awareness of the early signs of MBC, which may lead to delayed diagnosis but also to particular factors related to the histology of the breast in males as well as to the particular hormonal environment (10).

The pathological $(\mathrm{p}) \mathrm{T}$ classification data was available for 136 cases, and most of them were pT1 $(25.73 \%)$ or pT2 $(54.41 \%)$ with only $19.85 \%$ included in T3 and T4 category and only $3.68 \%$ of cases pT0. These results are similar with other studies, with $44 \%$ cases being diagnosed as pT1 category(12) and 54\% cases as pT1 (9), while $38 \%$ cases as pT2 (12) and $36 \%$ cases as pT2 $(9) ; 13 \%$ of cases were diagnosed as pT3 in Oger study and only 8\% cases in a study performed by Hong $(9,12)$.

In MBC, invasive carcinomas of no special type (NST) is the most common microscopic subtype similar to the most frequent type occurring in the FBC according to WHO classification (5). In our study, NST subtype was diagnosed in $86.63 \%$ of the patients, compared to $75 \%$ of NST cases in the study conducted by Hong, $81 \%$ by Humphries and $87 \%$ in Oger et al. research $(9,12,13)$. Invasive papillary carcinoma is more common in males than females, accounting for approximately $2-4 \%$ of cases due to the particularity of the breast histology in men, lacking acini development $(5,14)$. We diagnosed $1.38 \%$ carcinomas as invasive papillary subtype, while in the study by Hong et al., $6.8 \%$ of cases were of invasive papillary subtype (9). However, we had 6 additional cases of in situ papillary type (intracystic, solid, and encapsulated). Invasive lobular carcinomas are very rare in men, in our study being diagnosed in only $1.84 \%$ of patients. The rare frequency of invasive lobular carcinoma is again related to the fact that male breast carcinoma tissue is only represented by galactophorous ducts are rarely, due to hormonal influence, acini can develop. Other histological types of tumors such as invasive micropapillary carcinoma $(0.46 \%)$, carcinoma with neuroendocrine differentiation $(0.92 \%)$, and invasive apocrine carcinoma $(0.92 \%)$ are very rarely diagnosed in general and in particular in this series. The incidence of ductal carcinoma in situ is reported in up to $10 \%$ of all cases of MBC in the literature, in our study being diagnosed in $3.68 \%$ cases. Hong et al. reported DCIS in $6.8 \%$ of cases in a study comprising 59 male breast cancers (9).

In our study, most tumors show moderate or poor histological differentiation (G2: $55.4 \%$; G3: $25 \%$; G1:19.59\%), with $80.4 \%$ of them included in G2 and G3 category, similar with literature data $(80 \%$ cases were of G2/G3 histologic grade in a study performed by Fentiman (15), and $73 \%$ of cases were of G2/G3 histologic grade in a study performed by Hong $(9,15)$.

In our study, $65.89 \%$ of MBCs are associated with axillary lymph node metastasis, similar with other data reported by Hong paper in which $50 \%$ of cases developed axillary LNM and by Soliman et al. in which $77.2 \%$ of cases presented axillary LNM $(9,11)$. 
The incidence rates of the 4 clinicallydefined treatment oriented subtypes using immunohistochemistry were as follows: Luminal A-like (85.29\%), Luminal B-like (7.84\%), HER2-like (0.49\%) and TNBC (6.37\%); the most frequent subtypes encountered being Luminal A similar to the study performed by Chen et al (39.3\%)(16). However, in their study, Andre Saudade et al. analysed 196 cases and reported Luminal B subtype as being more frequent (45.3\%) than Luminal A (40.5\%), HER2 (6.8\%) and TN (7.4\%) (17).

In the present study, we found a higher incidence of hormone-receptor positivity than in women, which is consistent with published data (18). Of the 204 patients with available immunohistochemical data, $89.71 \%$ were positive for ER and $83.82 \%$ for PR, similar with data from literature. In the study by Masci et.al., ER was positive in $96.7 \%$ of male patients (18) while in the study by Oger et.al., $95 \%$ of MBC cases were positive for ER (12), while $97 \%$ of cases were ER-positive in the study of Serdy et al. (19) and $90.5 \%$ of cases in Hong et al. study (9). 84\% ER positivity was encountered in Humphries analyze (13). PR was positive in $92.3 \%$ of cases in the Masci et al. study, in $90 \%$ of cases in the study by Serdy et al., and in $64.3 \%$ of cases in the study by Hong et al. $(9,18,19)$. There is only one study performed on a small cohort $(69 \mathrm{MBC})$ in which the hormone receptor expression/status was very low, with only $42.1 \%$ hormone positive cases reported (11).

Due to the rarity of this disease, detailed data on HER2 expression are not available, and a wide range of HER2 positivity between $1 \%$ and $15 \%$ is reported in the literature (5). Some researchers suggest that the HER2 overexpression rates in $\mathrm{MBC}$ patients may be higher $(30-56 \%)$ than those in FBC patients (20) while others report lower HER2 overexpression rates in MBC $(2-18 \%)(3,13,21)$. In the present study, 17 of 204 (8.33\%) overexpressed HER2 (using IHC and fluorescent in situ hybridization). Masci et al. reported 14\% HER2 positivity (18), and Hong et al. 27.5\% (of 40 cases analyzed) (9). Discrepancies in the HER2 overexpression rates between these studies are likely explained by the small study population of each study as well as the heterogeneity in the included stages, ethnicity differences as well as different international cutoffs.

In addition to conventional morphological parameters, the assessment of the proliferation index is a major factor in treatment decision in breast carcinoma patients in some international medical centers. In our study, of the 121 cases in which the proliferative index using Ki67 assessment was performed, 30/121 $(24.79 \%)$ had a low Ki67 index $(<14 \%)$, while the majority had a high proliferative index (91/121) (75.21\%). In univariate analyses a higher Ki67 index is correlated with shorter survival, with a $\mathrm{HR}$ of dying of disease equal to $1.248(95 \% \mathrm{CI}=0.385-4.042)$, but not statistically significant $(p=0.712)$. Masci et al. concluded in their study comprising $96 \mathrm{MBC}$ that a high Ki67 index (>20\%) was statistically significant for overall survival on univariate analyses (5-year: $48 \%$ in patients with high Ki67 index versus $75.3 \%$ in patients with low Ki67 index) $(p=0.04)(18)$.

The expression of ER, PR, and HER2 as prognostic and/or predictive factors is very well established and has led to targeted treatment in breast carcinoma. However, triple negative patients (TNBC) are excluded from the benefits of such therapies in both women and men and need novel therapeutic targets (22). AR was the most frequently expressed of the hormone receptors in our study (with positivity in $93.29 \%$ of $\mathrm{MBC}$ ), similar with the results of Safarpour et al. ( $\mathrm{AR}+$ in $87.8 \%$ ), and Zhou et al. (AR+ in $84.2 \%$ of MBC) $(23,24)$. Of our TNBC cases in which $\mathrm{AR}$ was performed, (7/10) 70\% expressed AR while $30 \%$ were negative for AR. Cox analyses which compare AR+ versus AR- in TNBC patients revealed an $\mathrm{HR}=2.313$, $\mathrm{p}=0.499,95 \%$ $\mathrm{CI}=0.203-26.362$ ). In a previous study by our group, however, AR was expressed in all TNBC(22). Targeting the androgen receptor is becoming an exciting area of research in FBC also, as TNBC expressing the AR may behave with a less aggressive phenotype with a more indolent disease course. Further clinical application of these data may become available 
with the publication of the results from various ongoing clinical studies $(25,26)$. ARpositive luminal A male breast cancer had improved overall survival over female breast cancer at 5 years $(\mathrm{p}=0.01, \mathrm{HR}=0.39$, $95 \% \mathrm{CI}=0.26-0.87)$ in a study performed by Shaaban et al (27). Their data support the hypothesis that breast cancer is biologically different in males and females, suggesting implications for clinical management. Also, in Humphries's study which analyzed 446 MBC, in ERà+ cases only AR had prognostic significance, suggesting AR blockade could be employed therapeutically (13).

The median follow-up in our study was 59.6 months (range: 7-168 months), shorter than 69 months (Chen et al.) (16) and longer than 51.5 months in a study performed by Masci et al (18).

5-year OS was $67.2 \%$ in our study, compared with estimated OS by Kaplan Meier method in other studies like Masci: 68.1\%; Oger 79.2\%; Hong 62\%; Giordano 63\%; Chen $72.9 \%$; Soliman $46.6 \%(9,11,12,16,18,28)$. 10-year OS was $48.5 \%$ in our study lower than in other studies like Oger 70.8\%; Hong 44\%; Chen $53.9 \%)(9,12,16)$.

The Cox regression multivariate analysis of the factors associated with OS illustrated in Table 3 showed that the presence of $\mathrm{LN}$ metastases $(p=0.005)$ and triple negative molecular profile $(\mathrm{p}=0.05)$ were the only factors significantly associated with survival. Similar conclusions were reached by Soliman, with the only factors significantly affecting survival being $\mathrm{LN}$ involvement $(\mathrm{p}=0.001)$ and tumor grade $(p=0.03)$ (11). Other authors concluded that age, tumor size, and extracapsular extension in axillary lymph nodes with metastases significantly influenced prognosis in the study by Oger et al. (12) while age, higher stage, and tumor size are, according to the study by Ravi et al. (29), statistically significant for OS and high Ki67 proliferative index and adjuvant chemotherapy according to Masci et al (18). In a larger study performed on 512 cases the authors reported only the size of the tumor as the only prognostic factor associated with worse OS (30) (Table 4 ).

The strength of the present study is the large group size (data collected from 6 institutions from different continents including Europe, North and Central America). The study has limitations, however, including the lack of clinical, morphological, and immunohistochemical data in some of the cases and lack of follow-up in others. The findings and their implications should be discussed in the broadest context possible. Future research directions may also be highlighted.

Older age on diagnosis ( $>60$ years), positive LNM, larger tumor size, triple negative status, and the absence of oncological treatment are all negative factors influencing prognosis,

Table 4. Summary of studies analyzing prognostic factors associated with worse Overall Survival (OS)

\begin{tabular}{|c|c|c|c|}
\hline Study & $\begin{array}{l}\text { Number of } \\
\text { cases ( } n)\end{array}$ & Prognostic factors associated with worse OS & p-value \\
\hline Ravi et al.(29) & 29 & $\begin{array}{l}\text { Advanced age } \\
\text { Higher stage } \\
\text { Increasing tumor size }\end{array}$ & $\begin{array}{c}0.08 \\
0.055 \\
0.03\end{array}$ \\
\hline Masci et al.(18) & 97 & $\begin{array}{l}\text { Ki67 score }>20 \% \\
\text { Adjuvant CT } \\
\text { G3 }\end{array}$ & $\begin{array}{l}0.04 \\
0.024 \\
0.015\end{array}$ \\
\hline Oger et al.(12) & 95 & $\begin{array}{l}\text { Age } \\
\text { Tumor size } \\
\text { Histological capsular rupture }\end{array}$ & NA \\
\hline Soliman et al.(11) & 69 & $\begin{array}{l}\text { LN involvement } \\
\text { Advanced tumor grade }\end{array}$ & $\begin{array}{l}0.001 \\
0.03\end{array}$ \\
\hline Harlan et al.(30) & 512 & $\begin{array}{l}\text { Size } \\
\text { Current unmarried status }\end{array}$ & $\begin{array}{c}<0.0001 \\
0.04\end{array}$ \\
\hline
\end{tabular}


but statistically significant unfavorable independent prognostic parameter in multivariate analyses are axillary $\mathrm{LN}$ status $(\mathrm{p}=0.005)$ and triple negative molecular profile $(\mathrm{p}=0.05)$. Efforts should be made to diagnose MBC earlier to avoid higher stage on diagnosis. The data from this study corelated with recently published data in the literature suggest that $\mathrm{MBC}$ is most frequently positive for $\mathrm{AR}$ and most cases of MBC of triple negative profile are also AR positive. If future clinical trials support this conclusion, patients with MBC should be routinely tested for AR in addition to ER and PR and targeted treatment should be offered to AR positive patients to improve survival. Further research is needed to better understand the factors that affect this disease and appropriate screening may be warranted.

\section{Conflicts of Interest and Source of Funding:}

None declared.

\section{References}

1. Siegel R, Ma J, Zou Z, Jemal A. Cancer statistics. CA Cancer J Clin 2014;64(1):9-29.

2. American Cancer Society. Special Section: Rare Cancers in Adults. Available at: < https://www.cancer.org/content/dam/cancer-org/ research/cancerfacts-and-statistics/annual-cancer-facts-andfigures/2017/cancer-facts-and figures-2017-special-section-rarecancers-in-adults.pdf>. Last accessed on December 12, 2018.

3. Gómez-Raposo C, Zambrana Tévar F, Sereno Moyano M, López Gómez M, Casado E. Male breast cancer. Cancer Treatment Reviews. 2010;36(6):451-457

4. Wei JL, Zhang JX, Fu DY: Characterization and prognosis of estrogen receptor-positive/progesterone receptor-negative male breast cancer: a population-based study. World J Surg Oncol 2018; 16(1): 236

5. Lakhani S, Ellis I0, Schnitt SJ, Tan PH, van de Vijver MJ. WHO Classification of Tumours of the Breast. IARC press 2012, LYON; PP 10-71.

6. Ellis I0, Elston CW: Histological grade. In: F.P. O"Malley, SE Pinder (Eds). Breast Pathology. Elsevier, Philadelphia, PA, 2006; pp 22533, 2006.

7. Amin MB, Edge SB, Greene FL, Compton CC, Gershenwald JE, Brookland RK et al. AJCC cancer staging manual 2017, eight edition

8. Dowsett M, Nielsen TO, A'Hern R, Bartlett J, Coombes RC, Cuzick $\mathrm{J}$ et al. Assessment of Ki67 in breast cancer: recommendations from the International Ki67 in Breast Cancer working group. J Natl Cancer Inst 2011; 103(22):1656-64

9. Hong JH, Ha KS, Jung YH, Won HS, An, Lee GJ et al. Clinical Features of Male Breast Cancer: Experiences from Seven Institutions Over 20 Years. Cancer Res Treat 2016;48(4):1389-1398.

10. Miao H, Verkooijen HM, Chia KS, Bouchardy C, Pukkala E, Larønningen $S$ et al. Incidence and outcome of male breast cancer: an international population-based study. J Clin Oncol 2011;
29:4381-6

11. Soliman AA, Denewer AT, El-Sadda W, Abdel-Aty AH, Refky B. A retrospective analysis of survival and prognostic factors of male breast cancer from a single center. BMC Cancer 2014; 14:227

12. Oger AS, Boukerrou M, Cutuli B, Campion L, Rousseau E, Bussières $E$ et al. Male breast cancer: prognostic factors, diagnosis and treatment: a multi-institutional survey of 95 cases. Gynecol Obstet Fertil 2015:43(4):290-6.

13. Humphries MP, Sundara Rajan S, Honarpisheh H, Cserni G, Dent $J$, Fulford $L$ et al. Characterisation of male breast cancer: a descriptive biomarker study from a large patient series. Sci Rep. 2017;7:45293

14. Stolnicu, Simona, Alvarado-Cabrero, Isabel. Practical Atlas of Breast Pathology, Springer 2018, pp 15

15. Fentiman IS, Fourquet A, Hortobagyi GN: Male breast cancer. Lancet 2006; 367:595-604

16. Chen X, Liu X, Zhang L, Li S, Shi Y, Tong Z. Poorer survival of male breast cancer compared with female breast cancer patients may be due to biological differences. Jpn J Clin Oncol 2013; 43(10):954-63

17. André S, Pereira T, Silva F, Machado P, Vaz F, Aparício M et al. Male breast cancer: Specific biological characteristics and survival in a Portuguese cohort. Mol Clin Oncol 2019; 10(6):644-654

18. Masci G, Caruso M, Caruso F, Salvini P, Carnaghi C, Giordano L et al. Clinicopathological and Immunohistochemical Characteristics in Male Breast Cancer: A Retrospective Case Series. Oncologist 2015; 20(6):586-92

19. Serdy KM, Leone JP, Dabbs DJ, Bhargava R. Male Breast Cancer. Am J Clin Pathol. 2017; 147(1):110-119

20. Onami S, Ozaki M, Mortimer JE, Pal SK. Male breast cancer: an update in diagnosis, treatment and molecular profiling. Maturitas 2010; 65:308-14

21. Ottini L, Rizzolo P, Zanna I, Falchetti M, Masala G, Ceccarelli K et al. BRCA1/BRCA2 mutation status and clinical-pathologic features of 108 male breast cancer cases from Tuscany: a population-based study in central Italy. Breast Cancer Res Treat 2009;116:577-86.

22. Stolnicu S, Moncea D, Dema A, Geambasu S, Moldovan C, Comanescu $\mathrm{M}$ et al. Androgen Receptor (AR) Expression in Invasive Male Breast Carcinoma (MBC): An International MultiInstitutional Review of 168 Cases Emphasizing the Potential Use of AR as a Therapeutic Target. Appl Immunohistochem Mol Morphol 2017; 25(2):e18-e20

23. Safarpour D, Pakneshan S, Tavassoli FA: Androgen receptor (AR) expression in 400 breast carcinomas: is routine AR assessment justified? Am J Cancer Res 2014; 4(4):353-368.

24. Zhou R, Yu L, Zhou S, Bi R, Shui R, Yu B, et al. Male breast carcinoma: a clinicopathological and immunohistochemical characterization study. Int J Clin Exp Pathol 2014; 7(10):6852-6861.

25. Vidula $\mathrm{N}$ and Bardia $\mathrm{A}$ : Targeted therapy for metastatic triple negative breast cancer: The next frontier in precision oncology; Oncotarget 2017;8(63):106167-106168

26. Kensler KH, Regan MM, Heng YJ, Baker GM, Pyle ME, Schnitt SJ et al. Prognostic and predictive value of androgen receptor expression in postmenopausal women with estrogen receptor-positive breast cancer: results from the Breast International Group Trial 198. Breast Cancer Res. 2019;21(1):30

27. Shaaban AM, Ball GR, Brannan RA, Cserni G, Di Benedetto A, Dent $J$ et al. A comparative biomarker study of 514 matched cases of male and female breast cancer reveals gender-specific biological differencies. Breast Cancer Res Treat. 2012;133(3):949-58.

28. Giordano SH, Cohen DS, Buzdar AU: Breast carcinoma in men: a population-based study. Cancer 2004; 101(1):51-57.

29. Ravi A, Bang H, Karsif K, Nori D. Breast cancer in men: prognostic factors, treatment patterns, and outcome. Am J Mens Health. 2012; $6(1): 51-8$.

30. Harlan LC, Zujewski JA, Goodman MT, Stevens JL. Breast cancer in men in the United States: a population-based study of diagnosis, treatment, and survival. Cancer 2010;116(15):3558-68. 